\title{
Immunolocalization of PTHrP in the parotid glands of three rodents species: Clethrionomys glareoulus, Microtus arvalis and white Swiss mice
}

\author{
Elżbieta Czykier1, Maciej Zabel2,3, Jolanta Seidel² \\ ${ }^{1}$ Department of Histology and Embryology, Medical University of Białystok, \\ ${ }^{2}$ Department of Histology and Embryology, Medical University, Poznań \\ ${ }^{3}$ Department of Histology and Embryology, Medical Academy, Wrocław
}

\begin{abstract}
The current study was inspired by the fact that since 2004 no report had appeared on the occurrence of this peptide in healthy parotid glands of humans and animals. The objective of the current study was to investigate the immunolocalization of PTHrP in the parotid gland of three male rodents: 6 common voles (Microtus arvalis, Pallas, 1779), 6 bank voles (Clethrionomys glareoulus, Schreber, 1780) and 6 white Swiss mice, as well as to find out any species differences in the distribution of this peptide in various types of cells of the parotid gland. Immunocytochemical reactions were performed using the $\mathrm{ABC}$ technique with specific rabbit antibodies against human PTHrP (34-53) (CALBIOCHEM), diluted 1:70 and 1:50. We observed positive PTHrP expression in the epithelial cells of the striated duct in all the three animal species. The expression was strong in white mouse and very strong in common vole and bank vole. In all the rodent species studied, the reaction for PTHrP was granular in nature and irregularly distributed in the cytoplasm, being definitely stronger at the base and weaker at the apex of the cells. The PTHrP expression was negative in the epithelium of the intercalated duct, interlobular duct, main excretory duct, as well as in the myoepithelial cells surrounding the excretory ducts or serous acini.
\end{abstract}

Key words: PTHrP, immunocytochemistry, parotid glands, rodents

\section{Introduction}

Parathyroid hormone related peptide (PTHrP) was identified in 1987 while investigating humoral hypercalcemia (HHM) in patients with neoplastic disease. In the course of neoplastic disease, PTHrP causes hypercalcemia, hypophosphatemia and elevated cAMP values in urine [1-3]. The human PTHrP gene occurs on the short arm of chromosome 12 and consists of nine exons [4]. Two of these exons are found unchanged in PTHrP transcripts. The remaining seven exons are localized in altered combinations in PTHrP mRNA, which allows the formation of approximately 15 various transcripts [1]. The expression of PTHrP gene is regulated mainly on the transcription level through IL2 , TGF- $\beta$, IGF-I, EGF. The PTHrP mRNA is responsible for the formation of three peptide isoforms with

Correspondence: Elżbieta Czykier, Dept. of Histology and Embryology, Medical University of Białystok, Kiliński Str. 1, 15-230 Białystok, Poland; tel./fax. (+4885) 7485455, e-mail: czykier@umwb.edu.pl various chain length: 139, 141 and 173 amino acids [4-7]. Human tissues and neoplastic tumors may contain three transcripts, but some tissues show preference for one of the isoforms $[4,5,8]$.

Later studies have shown that PTHrP is produced not only in neoplastic tissues but also by many healthy human and animal tissues: thyroid gland, parathyroid gland, pituitary gland, salivary gland, urinary bladder, kidney, mammary gland, testis, epididymis, cartilage, osteoblasts, vascular smooth muscle cells [2,8-26]. PTHrP is a very conservative peptide. Its presence has been detected in the preimplantation period.

PTHrP expression has been identified in the submandibular and sublingual glands of rodents (rat, white mouse, bank vole, common vole, pine vole) and in the human parotid glands, both healthy and those affected by inflammation or neoplasm [9,27-30].

The current study was inspired by the fact that since 2004 no report had appeared on the occurrence of this peptide in healthy parotid glands of humans and animals. The aim of the current study was to investigate PTHrP immunolocalization in the parotid gland of three rodent species (white mouse, common vole and 
bank vole) as well as to assess any species differences in the distribution of this peptide in various types of parotid gland cells.

\section{Materials and methods}

Tissue collection. In the present study, we investigated parotid glands of adult male rodents: 6 common voles (Microtus arvalis, Pallas, 1779), 6 bank voles (Clethrionomys glareoulus, Schreber, 1780 ) and 6 white Swiss mice, which were obtained from the animal quarters of Białystok University. The mammals were anesthetized with $200 \mathrm{mg} / \mathrm{kg}$ pentobarbital sodium by intraperitoneal injection prior to cervical dislocation. The parotid glands were collected, fixed in Bouin's solution for $24 \mathrm{~h}$ and embedded in paraffin. Five $\mu \mathrm{m}$ sections were stained with hematoxylin and eosin $(\mathrm{H}+\mathrm{E})$.

Immunocytochemical procedures. Immunocytochemical reactions were performed using the $\mathrm{ABC}$ technique according to Hsu et al [31]. After blocking endogenous peroxidase activity with $1 \%$ $\mathrm{H}_{2} \mathrm{O}_{2}$ in distilled water, the sections were incubated for $30 \mathrm{~min}$ with normal goat serum $(1: 20)$. Next, they were incubated overnight at $4{ }^{\circ} \mathrm{C}$ with specific rabbit antibodies against human PTHrP (34-53) (Calbiochem, USA), diluted 1:70 and 1:50. This was followed by $30 \mathrm{~min}$ incubation with biotinylated anti-rabbit antibodies and by 1 hour incubation with the streptavidin-biotinylated peroxidase complex. Peroxidase activity was detected with DAB. Between the successive steps, sections were washed in PBS $(3 \times 3 \mathrm{~min})$. In negative controls, we omitted the primary antibody and used normal rabbit serum, the remaining stages being unchanged.

\section{Results}

We observed positive PTHrP expression in the epithelial cells that lined the striated duct in all the three animal species studied. Its intensity varied in a speciesdependent manner (Figs. 1A, 1B, 1C). The expression was found to be high in white mouse (Figs. 1A), and very high in common vole and bank vole (Figs. 1B, 1C). In white mouse, some of the epithelial cells lining the striated duct showed a strong reaction, others exhibited a weak reaction, whereas in single cells a trace reaction was observed (Fig. 1A). The reaction was granular in nature and unevenly distributed within the cytoplasm, being by far stronger at the cell base and weaker at the cell apex (Fig. 1A). Both in bank vole and in common vole the epithelial cells of the striated duct showed strong PTHrP staining as compared to white mouse (Figs. 1A, 1B, 1C). In these two species (bank vole and common vole), the intensity of PTHrP expression in the epithelial cells of the striated duct was equally high (Figs. 1B, 1C). It was, however, much more varied in bank vole (Fig. 1B): in some cells the reaction was very strong, in others strong or weak and in some even negative (Fig. 1B). In common vole, the intensity of PTHrP expression in the epithelial cells of the striated duct ranged from very strong to strong and weak (Fig. 1C). The cytoplasm of the striated duct epithelial cells in common vole and bank vole showed irregular PTHrP staining (Figs. 1B, 1C). The reaction, granular in nature, was much stronger at the cell base as compared to the apical part, like in white mouse (Figs. 1A, 1B, 1C). The granular nature of PTHrP expression was still predominant (Figs. 1B, 1C).

In our study, PTHrP expressions in the epithelium of the intercalated duct, interlobular duct and main excretory duct were negative in all the three animal species studied. We found no PTHrP expression in the myoepithelial cells surrounding the excretory ducts or serous acini.

\section{Discussion}

We found PTHrP expression in the epithelial cells of the striated duct of the parotid glands in all the three animal species examined, but not in the epithelial lining of the intercalated, interlobular and main excretory duct. Our results are similar to those reported by other authors. Also Zabel et al. [30] did not observe the presence of PTHrP in the epithelium of the intercalated duct in the healthy human parotid gland. However, these authors, unlike us, detected positive PTHrP staining in the epithelial cells of the interlobular and main excretory duct in the healthy human parotid gland. Also Seidel et al. [27] showed the expression of PTHrP in all the epithelial cells lining the excretory duct, both intra- and interlobular duct, in the human parotid and submandibular salivary glands. Likewise, Sunardi et al. [28] described a positive reaction for PTHrP in the epithelial cells of all the segments of the excretory ducts in the healthy human parotid gland. On the other hand, Czykier et al. [26] observed PTHrP expression in the epithelial lining in all types of the excretory ducts in the submandibular glands of white mouse, bank vole and pine vole. In the sublingual glands of white mouse, bank vole and common vole, these authors [32] found the presence of PTHrP in the epithelial cells of all the excretory ducts, except for the intercalated duct. Our previous and current findings demonstrate a substantial organ variation in PTHrP localization in rodent salivary glands. At the same time, literature data and our results seem to indicate that PTHrP belongs to the peptides that frequently occur in the epithelial cells of the excretory ducts of the salivary gland in various animal species.

We believe that PTHrP found in our study in the epithelial cells of the striated duct of the parotid gland, just like in the renal tubules, can play a role in the transport of electrolytes, especially calcium ions, as this peptide, together with $\mathrm{PTH}$, regulates calciumphosphate balance in the body. This has been confirmed by the findings reported by Dua et al. [33] on the sheep salivary gland. These authors [33] observed after PTHrP infusion (1-34) a significant increase in the total and ionized calcium concentration in plasma but not in saliva. In contrast, they noted a significant 

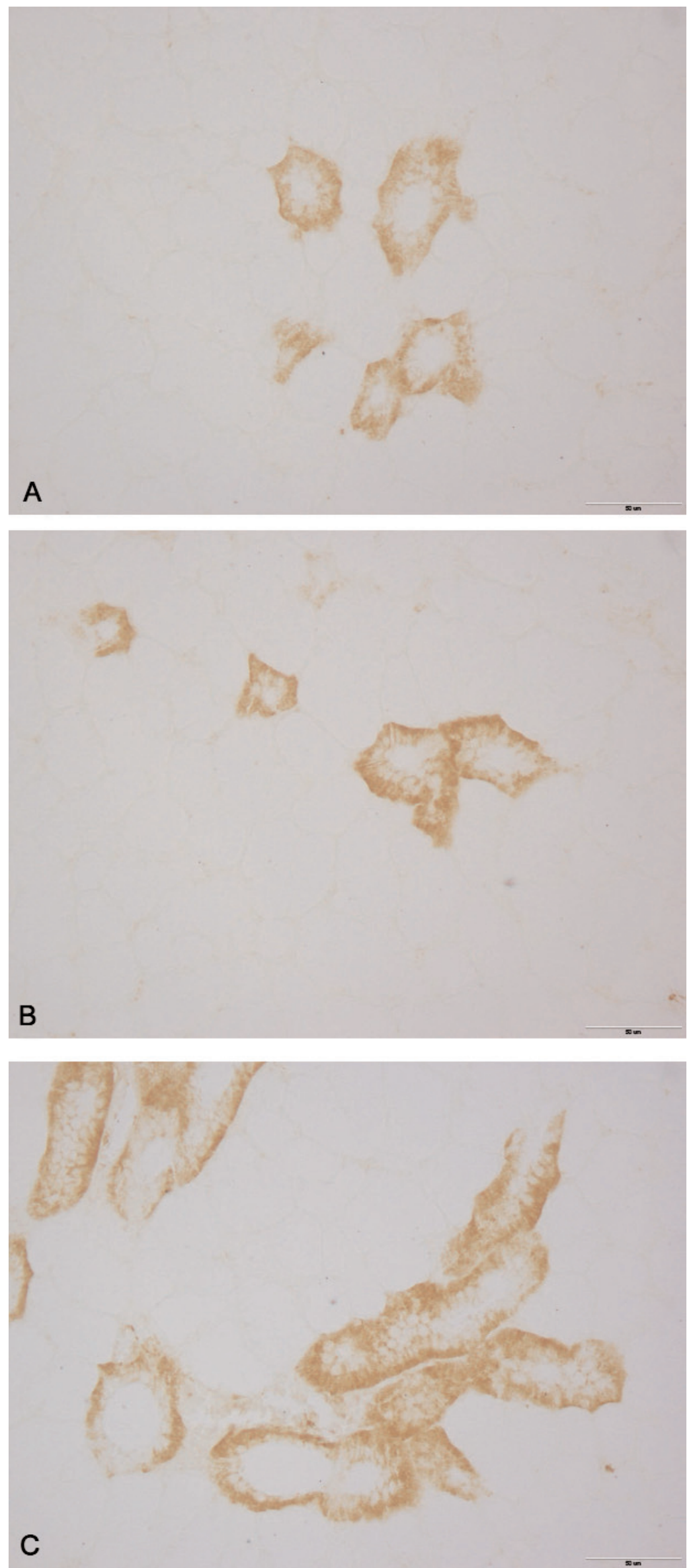

Fig. 1 PTHrP expression in the epithelium of the striated duct of parotid glands in (A) white mouse, (B) common vole, (C) bank vole. 
decrease in the plasma concentration of phosphate and potassium, and a corresponding increase in their salivary concentrations and clearance rates. Moreover, according to Esbrit et al. [34], PTHrP present in the epithelium of the renal canaliculi regulates their proliferation. In our opinion, PTHrP may have a similar role in the epithelial cells of the excretory ducts of the salivary glands in white mouse, bank vole and common vole.

Other authors have described PTHrP expression in the myoepithelial cells of the submandibular gland, mammary gland, small sweat gland and inflammatory human parotid secretory elements, in the culture of myoepithelial cells of the mammary gland $[9,22,30]$. Seitz et al. [35] have found out that PTHrP (1-34) causes an increase in intracellular cAMP in myoepithelial cell line derived from normal human breast. At the same time, these authors believe that PTHrP changes the intracellular $\mathrm{Ca}^{2+}$ response to oxytocin. We did not observe PTHrP expression in myoepithelial cells surrounding serous acini of the parotid gland.

Our findings concerning PTHrP expression in myoepitelial cells surrounding the excretory duct are consistent with observations reported by other authors, who have not detected PTHrP in these cells in any of the animal species examined $[9,27,28,30]$. Our current study concerning immunolocalization of PTHrP in the parotid glands of three rodents species is a continuation of our investigations of the occurrence of this peptide in submandibular and sublingual glands, and at the same time extends the knowledge of the subject that has not been researched since 2004 .

\section{References}

[ 1] Gillespie MT, Martin TJ. The parathyroid hormone-related protein gene and its expression. Mol Cell Endocrinol. 1994;100:143-147.

[2] Mundy GR. Hypercalcemia of malignancy revisited. J Clin Invest. 1988;82:1-6.

[3] Srirajaskanthan R, McStay M, Toumpanakis C, Meyer T, Caplin Me. Parathyroid hormone-related peptide- secreting pancreatic neuroendocrine tumors: cases series and literature review. Neuroendocrinology. 2009;89:48-55.

[4] Mangin M, Ikeda K, Dreyer BE, Broadus AE. Isolation and characterisation of the human parathyroid hormon-like peptide gene. Proc Natl Acad Sci USA. 1989;86:2408-2412.

[ 5] Brandt DW, Bruns ME, Bruns DE. The parathyroid hormonerelated protein $(\mathrm{PTHrP})$ gene preferentially utilizes a GC-rich promoter and the PTHrP 1-139 coding pathway in normal human amnion. Biochem Biophys Res Commun. 1992;189:938-945.

[ 6] Burtis WJ. Parathyroid hormone-related protein: structure, function and measurement. Clin Chem. 1992;38:2171-2183.

[ 7] Martin TJ, Gillespie MT, Williams E, Paspaliaris V, Danks JA, Moseley JM. Multiple sites of synthesis and action of parathyroid hormone-related protein. Mineral Electrol Metab. 1995;21:123-128.

[ 8] Thiede MA, Daifotis AG, Weir EC,Brines ML, Burtis WJ, Ikeda K, Dreyer BE, Garfeild RE, Broadus AE. Intrauterine occupancy controls expression of the parathyroid-related peptide gene in preterm rat myometrium. Proc Natl Acad Sci. USA 1990;87:6969-6973.

[ 9] Czykier E, Zabel M, Surdyk-Zasada J. Immunolocalization of PTHrP in the European bison and pine vole testis and epididymis. Folia Histochem Cytobiol. 2001;39:57-61.

[10] Czykier E, Zabel M, Surdyk-Zasada J. Immunolocalization of PTHrP in prepubertal and pubertal testis of European bison. Folia Histochem Cytobiol. 2002;40:373-375.

[11] Czykier E, Zabel M, Surdyk-Zasada J. Comparison of PTHrP expression in the epididymis of juvenile and adult European bisons. Folia Histochem Cytobiol. 2003;41:149-154.

[12] Danks JA, Ebeling PR, Hayman J, Chou ST, Moseley JM, Dunlop J, Kemp BE, Martin TJ. Parathyroid hormone-related protein: immunohistochemical localization in cancers and in normal skin. J Bone Mineral Res. 1989;2:273-278.

[13] Datta NS, Abou-Samra AB. PTH and PTHrP signalling in osteoblasts. Cell Signal. 2009;21:1245-1254.

[14] Harrington EK, Roddy GW, West R, Svoboda KK. Parathyroid hormone/parathyroid hormone-related peptide modulates growth of avian sternal cartilage via chondrocytic proliferation. Anat Rec. 2007;290:155-167.

[15] Jüppner H. Molecular cloning and characterization of a parathyroid homone/parathyroid hormone-related peptide receptor: a member of an ancient family of G protein-coupled receptors. Curr Opin Nephrol Hypertens. 1994;3:371-378.

[16] Kaiser SM, Laneuville P, Rhim JS, Kremer R, Goltzman D. Enhanced growth of a human keratinocyte cell line induced by antisense RNA for parathyroid hormone related peptide. J Biol Chem. 1992;261:13623-13628.

[17] Onda K, Matsuki N, Ono K, Wada Y. Expression of parathyroid hormone-related protein (PTHrP) mRNA in mam mary gland of periparturient cows. J Vet Med Sci. 2006;68:9-13.

[18] Orloff JJ, Reddy D, DePapp A, Yang KH, Soifer NE, Steward AF. Parathyroid hormone-related protein as a prohormone: posttranslational processing and receptor interactions. Endocr Rev. 1994;15:40-60.

[19] Perez-Martinez FC, Juan YS, Lin WY, Guven A, Mannikarottu A, Levin RM. Expression of parathyroid hormone-related protein in the partially obstructed and reversed rabbit bladder. Int Urol Nephrol. 2009;41:505-511.

[20] Pirola CJ, Wang HM, Strgacich MI, Kamyar A, Cercek B, Forrester JS, Clemens TL, Fagin JA. Mechanical stimuli induce vascular parathyroid hormone-related protein gene expression in vivo and in vitro. Endocrinology. 1994:134:2230-2236.

[21] Song GJ, Fiaschi-Taesch N, Bisello A. Endogenous parathyroid hormone-related protein regulates the expression of PTH type 1 receptor and proliferation of vascular smooth muscle cells. Mol Endocrinol. 2009;23:1681-1690.

[22] Sopel M and Lis A. Coexpression of PTHrP and PTH/PTHrP receptor in a myoepithelial cell line derived from normal human brest. Folia Cytochem Cytobiol. 2000;2:65-69.

[23] Thiede MA, Rodan GA. Expression of a calcium-mobilizing parathyroid hormone-like peptide in lactating mammary tissue. Science. 1998;242:278-280.

[24] Tian J, Smogorzewski M, Kedes L, Massry SG. Parathyroid hormone-parathyroid hormone related protein receptor messenger RNA is present in many tissue besides the kidney. $\mathrm{Am}$ J Nephrol. 1993;13:210-213.

[25] Yamamoto M, Harm SC, Grasser WA, Thiede MA. Parathyroid hormone-related protein in the urinary bladder: a smooth muscle relaxant produced locally in response to mechanical stretch. Proc Natl Acad Sci USA. 1992;89:5326-5330.

[26] Czykier E, Zabel M, Seidel J. Immunolocalization of PTHrP in the submandibular glands of three rodent species. Folia Histochem Cytobiol. 2001;39:325-329.

[27] Seidel J, Zabel M, Surdyk-Zasada J, Kasprzak A, Radziemski A. Immunocytochemical localization of PTHrP in human 
and rat salivary glands. Folia Histochem Cytobiol. 2001; $39 ; 171-172$.

[28] Sunardhi-Widyaputra S and Van Damme B. Parathyroid Hormone-related Peptide: Immunolocalisation in Normal Salivary Glands and in Pleomorphic Adenomas. Pathol Res Pract. 1995;192:15-19.

[29] Sunardhi-Widyaputra S, Van den Oord JJ, Van Houdt K, De Ley M, Van Damme B. Identification of metallothioniein- and parathyroid hormome-related peptide(PTHrP)-positive cells in salivary gland tumors. Pathol Res Pract. 1995;191:10921098.

[30] Zabel M, Murawski M, Surdyk-Zasada J, Salwa-Żurawska W, Radziemski A. Immunocytochemical localisation of PTHrP (parathormone-related peptide) in myoepithelial cells of human sweat and parotid glands. Folia Cytochem Cytobiol. 1999;3:167-172.

[31] Hsu Su-Ming, Raine L, Fanger H. Use of avidin-biotin-peroxidase complex $(\mathrm{ABC})$ in immunoperoxidase techniques: a comparison between $\mathrm{ABC}$ and unlabeled antibody (PAP) procedures. J Histochem Cytochem. 1981;29:577-580.
[32] Czykier E, Zabel M, Seidel J. Immunolocalization of PTHrP in the sublingual glands of three mammals. Folia Histochem Cytobiol. 2003;41:29-32.

[33] Dua K, Abbas SK, Care AD. The secretion of parathyroid hormone-related protein in the saliva of sheep and its effects on the salivary clearance of phosphate, calcium, magnesium, potassium and sodium ions. Exp Physiol. 1995;80:589-595.

[34] Esbrit P, Santos S, Ortega A, Fernandez-Agullo T, Velez E, Troya S, Garrido P, Pena Antonio, Bover J, Bosch RJ. Parathyroid hormone-related protein as a renal regulating factor. Am J Nephrol. 2001;21:179-184.

[35] Seitz PK, Cooper KM, Ives KL, Ishizuka J, Townsend CM Jr, Rajaraman S, Cooper CW. Parathyroid hormone-related peptide production and action in a myoepithelial cell line derived from normal human breast. Endocrinology. 1993;133:11161124.

Submitted: 10 October, 2009 Accepted after reviews: 11 February, 2010 